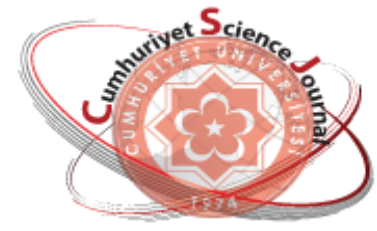

e-ISSN: $2587-246 X$

ISSN: $2587-2680$

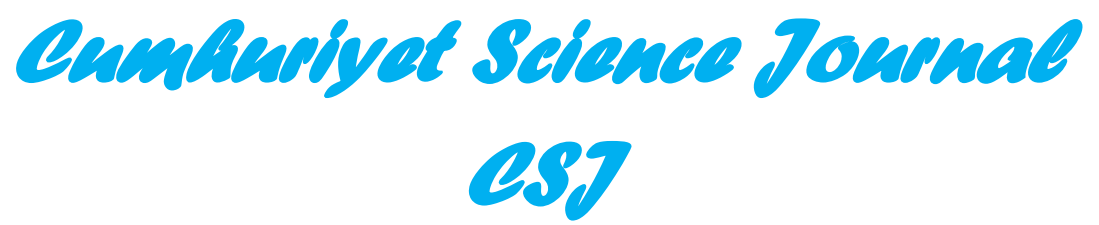

Cumhuriyet Sci. J., Vol.40-2(2019) 440-446

\title{
Antimutagenic and Multi-Biological Activities of Smilax excelsa L. Fruit Extract
}

\author{
Ecehan EFE ${ }^{1}$ (D), Emine YALÇIN ${ }^{*}$ (i), Kültiğin ÇAVUŞOĞLU ${ }^{1}$ \\ ${ }^{1}$ Giresun University, Faculty of Arts and Science, Department of Biology, Giresun, TURKEY
}

Received: 16.01.2019; Accepted: 25.04.2019

http://dx.doi.org/10.17776/csj.513469

\begin{abstract}
In this study, antimutagenic, antimicrobial and antioxidant activities of Smilax excelsa L. fruit extract were evaluated. The antimicrobial effect was investigated by disk diffusion method and the antimutagenic effect was investigated by Ames/Salmonella/microsom test. The antioxidant properties of S. excelsa fruit samples were determined by investigating the total phenolic, flavonoid contents and 1,1diphenyl-2-picrylhydrazyl (DPPH) radical scavenging activity. It was observed that $200 \mathrm{mg}^{\text {plate }}{ }^{-1}$ fruit extract was found to have a mutagenicity inhibition as $81 \%$ in the absence of S9 mixture and $67 \%$ in the presence of S9 mixture against Salmonella typhimurium TA1535. S. excelsa fruit extract produced an inhibition zone in the range of $11-16 \mathrm{~cm}$ against the tested microorganisms. Flavonoid and phenolic contents were found to be $0.7985 \pm 0.0124 \mathrm{mgQE} 100 \mathrm{~mL}^{-1}$ and $11.9847 \pm 0.0041 \mathrm{mgGAE} 100 \mathrm{~mL}^{-1}$ at the $200 \mathrm{mg} \mathrm{mL}^{-1}$ extract concentration, respectively. The DPPH removal rate was determined to be $55 \%$ at the $200 \mathrm{mg} \mathrm{L}^{-1}$ dose. As a result, it was observed that the $S$. excelsa fruit tissues exhibited a highly antimutagenic activity and has been determined as a potential natural antimicrobial and antioxidant source.
\end{abstract}

Keywords: Ames/Salmonella/microsomal test, antioxidant activity, disc diffusion test, Smilax excelsa.

Smilax excelsa L. Meyve Ekstresinin Antimutagenik ve Multi-Biyolojik aktiviteleri

Özet. Bu çalışmada, Smilax excelsa L. meyve ektraktının antimikrobiyal, antioksidan ve antimutajenik aktiviteleri araştırılmıştır. Antimikrobiyal aktivite disk difüzyon yöntemi ile antimutajenik aktivite ise Ames/Salmonella/mikrozom testi kullanılarak araştııılmıştır. S. excelsa meyve örneklerinin antioksidan özelliği ise toplam fenolik ve flavonoid içeriğinin tespiti ve 1,1-difenil-2-pikrilhidrazil (DPPH) giderme etkisi

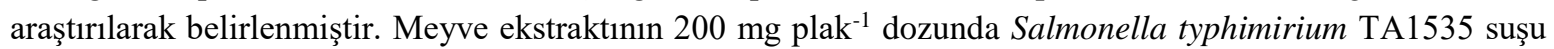
ile S9 karışımı yokluğunda \%81, S9 karışımı varlığında ise \%67 oranında mutajenite inhibisyonu oluşturduğu belirlenmiştir. S. excelsa meyve eksraktının test edilen mikroorganizmalara karşı 11-16 $\mathrm{cm}$ aralığında inhibisyon zonu oluşturduğu gözlenmiştir. $200 \mathrm{mg} \mathrm{mL}^{-1}$ konsantrasyonunda ekstraktta flavonoid içeriği $0.7985 \pm 0.0124 \mathrm{mgQE} 100 \mathrm{~mL}^{-1}$ olarak, fenolik içerik ise $11.9847 \pm 0.0041 \mathrm{mgGAE} 100 \mathrm{~mL}^{-1}$ olarak tespit edilmiştir. $200 \mathrm{mg} \mathrm{L}^{-1}$ dozunda DPPH giderme oranı $\% 55$ olarak belirlenmiştir. Sonuç olarak, S. excelsa meyve dokularının yüksek antimutajenik aktivite sergilediği, potansiyel doğal bir antimutajenik ve antioksidan kaynak olduğu olduğu belirlenmiştir.

Anahtar Kelimeler: Ames/Salmonella/mikrozomal test, antioksidan aktivite, disk difüzyon testi, Smilax excelsa. 


\section{INTRODUCTION}

The accelerated industrialization has increased the use of chemicals in various sectors, and this increase has brought the need for natural components that can eliminate the negative effects of the chemicals. Natural components that can reduce the toxicity of chemicals on living organisms can be consumed as a drug or as a diet in daily consumption. Different tissues of the plants play a protective role against many diseases such as acute/chronic diseases and degenerative defects resulting from the adverse effects of chemicals. This feature of plants is related to the active ingredients found in different tissues with different ratios. It is suggested that regular use of these active compounds in daily life may be effective in preventing cancer and genetic diseases $[1,2]$. And also by this way, the secondary diseases caused by synthetic drugs, drug side effects and over-loading of the drug will be prevented [3, 4]. In this study, antimicrobial, antioxidant and antimutagenic activities of $S$. excelsa fruit extract were investigated.

Smilax excelsa L. belongs to the family of Smilacaceae, and these family members are woody, spiny, perennial plants that can be sized up to $15 \mathrm{~m}$, with an average length greater than 3 $\mathrm{m}$. In the Smilacaceae family $S$. medica, $S$. ornata, S. officinalis, S. syphilitica, S. papyracea species are grown in Central America, S. aspera and $S$. excelsa species are grown in Anatolia. S. excelsa, which is widespread throughout Northern Anatolia, has narrow, cylindrical roots and bakka type fruit [5, 6]. The shoots of $S$. excelsa, which is a spiny plant and started to give young shoots in spring, are consumed as vegetable. The rhizomes have various pharmacological properties such as immunomodulator, antibacterial, antifungal and antioxidant. S. excelsa has a variety of active ingredients. These active ingredients are responsible for the antitumor, anti-mutagenic, antibacterial, antifungal, antioxidant, antiinflammatory properties of Smilax species. It is reported that $S$. excelsa, which is known for its blood cleaning and perspiration, is used for therapeutic purposes in the syphilis [7-9].
Because of its importance and frequently consumption in the Black Sea Region, antimicrobial, antioxidant and antimutagenic activities of $S$. excelsa fruit extract have been investigated. Antimicrobial activity was determined by disc diffusion method, antimutagenic activity was determined by Ames/Salmonella test, antioxidant activity was determined by total phenolic content, flavonoid content analysis and 1,1-diphenyl-2picrylhydrazyl (DPPH) radical scavenging activity test.

\section{MATERIALS AND METHODS}

\subsection{Sample Preparation and Extraction}

$S$. excelsa fruit samples were dried under sterile conditions in an oven at $30^{\circ} \mathrm{C}$. After grinding samples, $0.2 \mathrm{~g}$ of ground sample was extracted in $10 \mathrm{ml}$ of methanol at room temperature for 24 hours in a shaking incubator. At the end of the incubation period, the extract was filtered to remove solid particles and the filtrate was centrifuged at $10000 \mathrm{rpm}$ for 10 minutes. After centrifugation, the supernatant was evaporated by using liquid phase evaporator. Extracts were stored at $-18^{\circ} \mathrm{C}$ and used for determine the antimicrobial, antioxidant and antimutagenic activity [10].

\subsection{Antimicrobial Activity}

The antimicrobial activity of $S$. excelsa fruit extract was determined by using disc diffusion method with the strains of Escherichia coli, Pseudomonas aeruginosa, Staphylococcus aureus, Klebsiella pneumonia, Streptococcus mutans, Staphylococcus epidermidis, Candida albicans and Candida krusei. Fresh inoculum of strains $\left(10^{7}-10^{8}\right.$ pcs $\left.L^{-1}\right)$ was spread over the surface of Mueller Hinton Agar plates. The sterile filter paper and standart antibiotic discs $(6 \mathrm{~mm})$ were placed over the medium surface and $20 \mathrm{mg} \mathrm{mL}^{-1}$ extract were impregnated to free sterile discs (20 $\mu l$ disc $\left.^{-1}\right)$. Plates were incubated for 1 hour at $4{ }^{\circ} \mathrm{C}$ and then for $18-24$ hours at $37{ }^{\circ} \mathrm{C}$ [11]. At the end of the period, the inhibition zones formed around the disc were evaluated as $\mathrm{mm}$. 


\subsection{Antioxidant Activity}

\subsubsection{Total Phenol and Flavonoid Determination}

The phenolic content of $S$. excelsa fruit extract was determined by Folin-Ciocaltaeu method. Gallic acid was used as standard material with five different concentrations. For experimental procedures, $0.5 \mathrm{~mL}$ of the sample in $2.5 \mathrm{~mL}$ of Folin-Ciocaltaeu reagent $(10 \%)$ and $7.5 \mathrm{~mL}$ of $\mathrm{Na}_{2} \mathrm{CO}_{3}(20 \%)$ were mixed in a test tube. The mixture was incubated at room temperature in the dark for 2 hours and then the absorbance was determined spectrophotometrically at $750 \mathrm{~nm}$ [12]. The total phenolic concentration was estimated as equivalent gallic acid (mg GAE 100 $\left.\mathrm{mL}^{-1}\right)$.

For flavonoid determination, quercetin as a standard substance was prepared in methanol at concentrations of $50-200 \mathrm{mg} \mathrm{L}^{-1} .10 \mathrm{~mL}$ of the sample was mixed with $1 \mathrm{~mL}$ of sodium nitrite (5\%) and allowed to stand for 6 minutes, after 1 $\mathrm{mL}$ of aluminum nitrate $(10 \%)$ was added. The mixture was left to stand for $6 \mathrm{~min}, 10 \mathrm{~mL} \mathrm{NaOH}$ (4.3\%) was added and then the volume was completed to $25 \mathrm{~mL}$ with $\mathrm{dH} 2 \mathrm{O}$. After incubation for $15 \mathrm{~min}$ at room temperature, the absorbance of the solution was determined spectrophotometrically at $510 \mathrm{~nm}$ [13]. Total flavonoid content was expressed in mg QE 100 $\mathrm{mL}^{-1}$.

\subsubsection{DPPH Assay}

The DPPH method was used to determine the radical scavenging activity of the $S$. excelsa fruit extract. For this aim, fruit extracts, BHA and BHT solutions were prepared at a concentration of 50$200 \mathrm{mg} \mathrm{L}^{-1}$. BHA and BHT were used as the standard substance. $80 \mu \mathrm{l}$ of samples were mixed with $1185 \mu \mathrm{l}$ DPPH $\left(6 \times 10^{-5} \mathrm{M}\right)$ solution. The mixture was allowed to stand in the dark for 60 minutes and at the end of time the absorbance of the solution was determined spectrophotometrically at $517 \mathrm{~nm}$. DPPH radical scavenging activity as \% Inhibition was calculated from the following equation [14].

$\%$ Inhibition $=\mathrm{Abs}$ control- Abs sample $/$ Abs control $\mathrm{X} 100$

\subsection{Antimutagenic Activity}

The antimutagenic activities of $S$. excelsa fruit extracts were determined by Ames/Salmonella test with the strains of mutant S. typhimurium TA1535 $[15,16]$. For this aim, the mutagenity inhibition rates of extract against mutagenic substances have been investigated. $100 \mu$ l bacterial strain (1-2 x $10^{9}$ bacteria $\left.\mathrm{mL}^{-1}\right), 100 \mu \mathrm{l}$ extract, $100 \mu \mathrm{l}$ sodium azide as positive mutagen solution and $500 \mu \mathrm{l}$ S9 mixture or phosphate buffer (for S9 (-) assay) were added to $2.5 \mathrm{ml}$ top agar. The mixture was shaken with vortex and poured onto the surface of minimal glucose agar plates and the plates were allowed to incubate at $37^{\circ} \mathrm{C}$ for $48-72$ hours. At the end of the incubation period the revertant colonies were counted by Stuart Colony meter. The rate of mutagenity in plates without extract, only contain bacterial strain and mutagenic material, was accepted as $100 \%$ (ie $0 \%$ antimutagenicity). The antimutagenic activities of the extracts were evaluated by using the following equation.

Antimutagenic activity $(\%)=[(\mathrm{A}-\mathrm{B}) /(\mathrm{A}-\mathrm{C})] \times 100$

(A: Numbers of revertant colonies in bacteria and mutagen containing plate; B: Numbers of revertant colonies in bacteria, mutagen and extract containing plate; C: Numbers of self-returning revertant colonies).

\section{RESULTS}

In this study, antimicrobial, antioxidant and antimutagenic activities of $S$. excelsa fruit extract were investigated. The antimicrobial activity of $S$. excelsa fruit extract is given in Figure 1. To determine the change of antimicrobial activity according to microorganism species, disc diffusion method was tested against fungi, gram positive and gram negative bacteria. It was determined that $S$. excelsa fruit extract showed different antimicrobial activity against all tested microorganisms. The maximum antimicrobial effect of extract was obtained with a $16 \mathrm{~mm}$ inhibition zone against $E$. coli. The lowest antimicrobial effect was obtained with $11 \mathrm{~mm}$ inhibition zone against $S$. aureus. In general, it has been determined that fruit extracts are more effective against gram-negative bacteria compared to gram-positives and fungi. It is also an essential 
point that the extracts have an antimicrobial activity against Klebsiella pneumonia and Candida albicans strains in which the test antibiotics are ineffective.

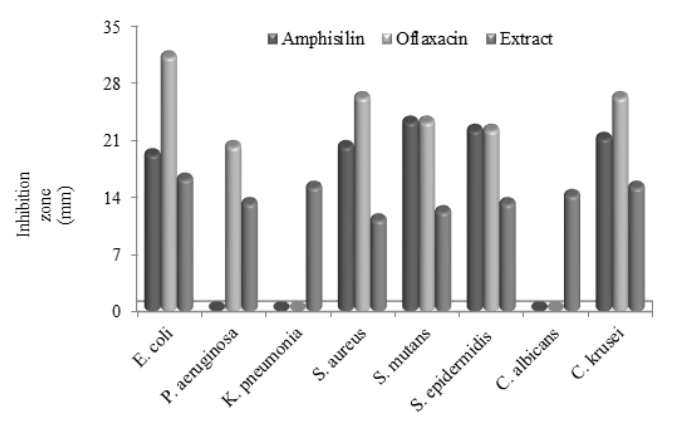

Figure 1. The antimicrobial activity of $S$. excelsa fruit extract

The phenolic content of $S$. excelsa fruit extract was determined by Folin-Ciocaltaeu. Phenolic and flavonoid contents were investigated at a concentration of $200 \mathrm{mg} \mathrm{mL}$. The flavonoid content of extract was determined as $0.7985 \pm 0.0124 \mathrm{mgQE} 100 \mathrm{~mL}^{-1}$ and the phenolic content was determined as $11.9847 \pm 0.0041$ mgGAE $100 \mathrm{~mL}^{-1}$.

One of the methods used for evaluating antioxidant activity is the DPPH radical scavenging activity assay. DPPH removal activity of $S$. excelsa fruit extract investigated in this study is given in Figure 2. Standard substances and extract were tested at concentrations of 50-200 mg $\mathrm{L}^{-1}$ and it was determined that the DPPH removal efficiency increased with increasing the concentration of each sample. The highest radical scavenging activity for BHA, BHT and fruit extracts at the concentration of $200 \mathrm{mg} \mathrm{L}^{-1}$ was found as $85 \%, 80 \%$ and $55 \%$, respectively. The DPPH scavenging activity obtained at the $200 \mathrm{mg}$ $\mathrm{L}^{-1}$ dose of the fruit extract was 1.7 times higher than the effect obtained at the concentration of 50 $\mathrm{mg} \mathrm{L} \mathrm{L}^{-1}$. The DPPH removal effect of the extract may be associated with the active ingredients, especially the antioxidant phenolic compounds.

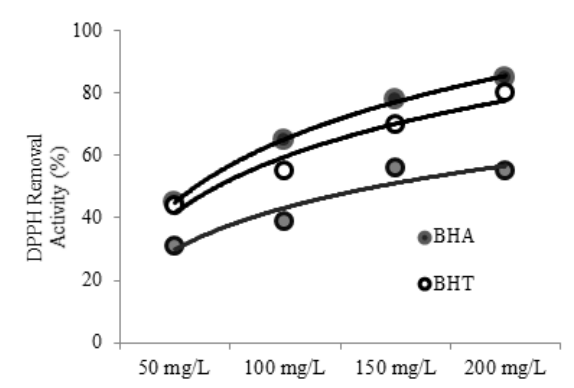

Figure 2. DPPH removal activity of S.excelsa fruit extract

The antimutagenicity test results of $S$. excelsa fruit extract against TA 1535 strain are given in Figure 3 and 4. It was determined that $200 \mathrm{mg}$ plate $^{-1}$ fruit extract caused an inhibition rate of $81 \%$ in the absence of S9 mixture. The inhibition rate increased with the extract dose increased and the inhibition rate obtained with $200 \mathrm{mg}$ plate $^{-1}$ extract was found to be 1.37 times higher than that obtained with $50 \mathrm{mg}$ plate ${ }^{-1}$ extract. When the percentages of inhibition were evaluated, it was determined that the $50-200 \mathrm{mg}$ plate $^{-1}$ extracts exhibited strong antimutagenic activity in the absence of S9 mixture. In the presence of S9 mixture, the fruit extract was resulted an inhibition rate of $67 \%$ against TA 1535 strain at $200 \mathrm{mg}$ plate $^{-1}$ extract. It was determined that the inhibition rate obtained with the $200 \mathrm{mg}$ plate $^{-1}$ extract increased by 1.48 times as much as that obtained with the $50 \mathrm{mg}$ plate $^{-1}$. It was also determined that the inhibition results obtained in the presence of the S9 mixture are lower than those obtained in the absence of the $S 9$ mixture.

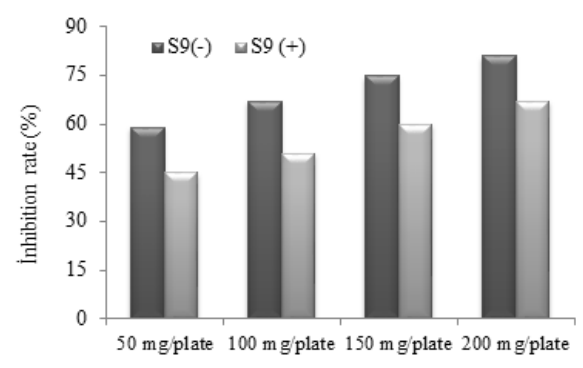

Figure 3. Antimutagenic activities of $S$. excelsa fruit extracts against TA 1535 


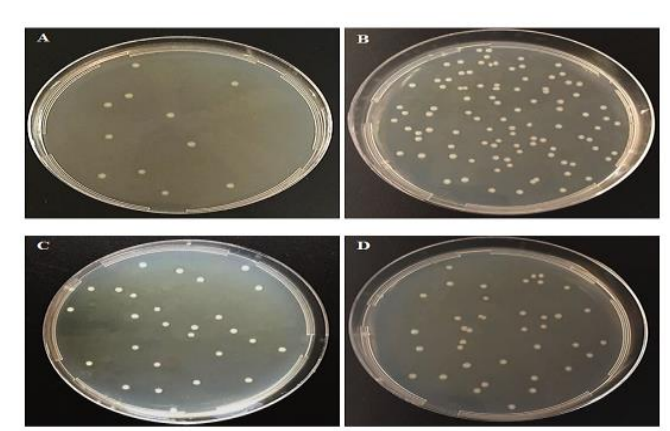

Figure 4. A: self-returning revertant colonies, B: revertant colonies in bacteria and mutagen containing plate, $\mathrm{C}$ : revertant colonies in bacteria, mutagen and $200 \mathrm{mg}$ plate $^{-1}$ extract containing plate in the absence of S9 mixture, D: revertant colonies in bacteria, mutagen and $200 \mathrm{mg}$ plate $^{-1}$ extract containing plate in the presence of $\mathrm{S} 9$ mixture

\section{DISCUSSION}

With the increase of mutagenic, carcinogenic and contaminant chemical compounds, the importance of antimicrobial, antioxidant and antimutagenic compounds in the natural structure is increasing day by day. There are many studies on the antimicrobial, antiviral and antioxidant effects of naturally active compounds. However, the increasing frequency of cancer diseases increases the importance of natural products with anticarcinogenic or antimutagenic activity. Although there are many studies on antimutagenic effects but the diversity of natural sources makes these studies insufficient. In this study, antimicrobial, antioxidant and antimutagenic activities of $S$. excelsa fruit extract were investigated. It was determined that the fruit extract provided $81 \%$ protection against mutagenity in the absence of S9 mixture at 200 mg plate ${ }^{-1}$ dose. In the presence of S9 mixture, it was determined that it provides $67 \%$ protection. Based on the inhibition percentages, it was determined that $S$. excelsa fruit extracts exhibited strong antimutagenic activity. In literature, catechin [8], trans-resveratrol, 5-Ocaffeoylbicimic acid, 6-O-caffeoyl- $\beta$-Dfructofuranosyl-(2 $\rightarrow 1)-\alpha$-D glucopyranozide [17] and phytochemical compounds [18] are reported in Smilax tissues. And also in this study the presence of phenolic and flavonoid compounds in
S. excelsa fruit extracts was determined. These compounds have antioxidant effect and provide protection against oxidative stress and thus show anti-mutagenic properties.

S. excelsa fruit extract showed different antimicrobial effect with the $11-16 \mathrm{~cm}$ inhibition zone range against tested microorganisms. This antimicrobial activity was comparable to the effect of the ampicillin and oflaxacin antibiotics tested in the study. It was determined that the oflaxacin did not show activity against $K$. pneomoniae and $C$. albicans and ampicillin did not show activity against $P$. aureginosa, $K$. pneomoniae and $C$. albicans. However, the fruit extract was also effective on these bacteria and showed a broad-spectrum antimicrobial activity. The antimicrobial activity exhibited by Smilax species is due to phenolic acids and the structure of the phenol group is very important in antimicrobial action. Oxygen-free phenolic compounds having a $\mathrm{C} 3$ side chain are classified as essential oils and exhibit high antimicrobial activity [19]. Ozsoy et al. [8] reported the presence of catechin in $S$. excelsa tissues. The antimicrobial effect observed in this study can be related to catechin which is the most reduced form of the $\mathrm{C}_{3}$ unit from the flavonoid compounds. Another important detail of this study is that fruit extract exhibit higher antibacterial properties against gram negative bacteria than gram positive bacteria. This result can be explained by the structural differences of gram-positive and gramnegative cells. Gram-positive bacteria have thick peptidoglycan layer, while gram-positive bacteria have a thin layer. This layer acts as a barrier to reduce the transport of external molecules to the gram positive bacteria and reduces the toxic effects of extract. This structural differentiation makes the gram positives more resistant to antimicrobial agents and the gram negatives to be more sensitive to these agents [20].

The antioxidant property of $S$. excelsa fruit extract was evaluated by the DPPH removal activity, total phenolic and flavonoid content of extract. In 200 $\mathrm{mg} \mathrm{mL}^{-1} S$. excelsa fruit extract concentration, flavonoid and phenolic content were determined 
as $\quad 0.7985 \pm 0.0124 \quad \mathrm{mgQE} \quad 100 \mathrm{~mL}^{-1}$ and $11.9847 \pm 0.0041 \mathrm{mgGAE} 100 \mathrm{~mL}^{-1}$, respectively. The DPPH removal rate of BHA, BHT and S. excelsa fruit extract was found to be $85 \%, 80 \%$ and $55 \%$, respectively. In the literature, antioxidant activity activities of S.excelsa and different Smilax species have been reported. Ozsoy et al. [8] reported that $S$. excelsa leaf extracts have a total phenol content of 8.8-35.7 GAE mg g ${ }^{-1}$ and a flavonoid content of 0.61-28.7 $\mathrm{mg} \mathrm{g}^{-1}$ catechin equivalent. Khaligh et al. [17] reported the isolation of trans-resveratrol, 5-Ocaffeoylshikimic acid, 6-O-caffeoyl- $\beta$-Dfructofuranosyl- $(2 \rightarrow 1) \quad-\alpha$-D glucopyranozide structures from $S$. excelsa tissues. And the antioxidant activity exhibited by the tissues was associated with these structures. The flavonoid and phenolic structures presence in the Smilax tissues have an active role in the prevention of diseases such as cardiovascular diseases, cancer and chronic inflammation by preventing free oxygen radicals and lipid peroxidation [21]. It is also known that flavonoids and phenolic compounds inhibit the enzymatic system involved in the radical formation of flavonoids, and decrease lipid oxidation by binding metal ions [9]. And also many studies have shown that these structures have antimutagenic and anticarcinogenic effects [18, 22].

\section{CONCLUSION}

Plant tissues have been used for many years in the treatment of various diseases. Increased industrial pollution and the access of contaminants to people through food chain has increased the risk of many diseases, especially cancer. In parallel with this increase, the use of synthetic drug substances increased, the side effects of drugs and the formation of various resistance mechanisms of microorganisms have brought the usage of plants for therapeutic purposes. For this aim, in literature many effects of plant tissues such as antifungal, antioxidative, antibacterial, antimutagenic, antiviral and anticarcinogenic have been studied. In this study, antimicrobial, antioxidant and antimutagenic activities of $S$. excelsa fruit exract, which is consumed as food in the Black Sea
Region, were investigated. It was determined that the fruit extracts exhibited antimicrobial activity against E.coli, P. aureginosa, S. aureus, $K$. pneumoniae, $S$. mutans, $S$. epidermidis, $C$. albicans and C. krusei. And also, fruit extracts have a high antioxidant phenolic and flavonoid content and have a significant DPPH removal effect as $85 \%$. In the antimutagenic activity assay, it was determined that the fruit extract inhibited mutagenicity in the $67-81 \%$ range and could be classified as a strong antimutagenic compound. As a result, it was determined that $S$. excelsa fruit tissues are a potential natural antimicrobial and antimutagenic source and exhibit strong antioxidant activity.

\section{REFERENCES}

[1] Stein C.M., Are herbal products dietary supplements or drugs? An important question for public safety, Clin. Pharmacol. Ther., 71-6 (2002) 411-413.

[2] Süzer Ö., Serotonin, Serotonin Reseptörlerinin Baslica Etki Yerleri Ve Fonksiyonlari. Süzer Farmakoloji. 3. bask1. Istanbul: Klinisyen Tip Kitabevleri, (2005) 150-154.

[3] IARC Monographs on the Evaluation of Carcinogenic Risks to Humans. Address: https://monographs.iarc.fr/wpcontent/uploads/2018/06/mono94-4.pdf.

Retrieved January 9, 2019.

[4] Navarro M., Montilla M.P., Cabo M.M., Galisteo M., Cáceres A., Morales C. and Berger I., Antibacterial, antiprotozoal and antioxidant activity of five plants used in Izabal for infectious diseases, Phytother. Res., 1 (2003) 325-329.

[5] Lee S.E., Ju E.M. and Kim J.H., Free radical scavenging and antioxidant enzyme fortifying activities of extracts from Smilax china root, Exp. Mol. Med., 33 (2001) 263-268.

[6] Jiang J. and Xu Q., Immunomodulatory activity of the aqueous extract from rhizome of Smilax glabra in the later phase of adjuvantinduced arthritis in rats, J. Ethnopharmacol., 85 (2003) 53-59.

[7] Ozbucak T.B., Ergen A.O. and Yalcin S., Nutrition contents of the some wild edible 
plants in Central Black Sea region of Turkey, IJNES, 1 (2007) 11-13.

[8] Ozsoy N., Can A., Yanardag R. and Akev N., Antioxidant activity of Smilax excelsa L. leaf extracts, Food Chem., 110 (2008) 571-583.

[9] Ozsoy N., Okyar A., Arda-Pirincci P., Can A., Bolkent S. and Akev N., Evaluation of Smilax excelsa L. use in experimentally induced nephrotoxicity, J. Fac. Vet. Med. Kafkas University, 19-5 (2013) 807-814.

[10] Efe E. Smilax excelsa L. meyve ekstrelerinin antimutajenik, antimikrobiyal ve antioksidan aktivitelerinin araştırılması. Giresun University Graduate School of Natural and Applied Sciences, Deparment of Biology, Master Thesiss. 16 (2017).

[11] Cooper D.G. and Paddock P.A., Production of a biosurfactant from Torulopsis bombicola, Appl. Environ. Microbiol., 47-1 (1984) 173176.

[12] Singleton V.L. and Rossi J.A., Colorimetry of total phenolics with phosphomolybdicphosphotungstic acid reagents, Am. J. Enol. Viticult., 16 (1965) 144-158.

[13] Zhishen J., Mengcheng T. and Jianming W., The determination of flavonoid contents on mulberry and their scavenging effects on superoxide radical, Food Chem., 64 (1999) 555-559.

[14] Yen G.C. and Duh P.D., Scavenging effect of methanolic extracts of peanut hulls on freeradical and active oxygen species, J. Agric. Food Chem., 42 (1994) 629-632.

[15] Maron D.M. and Ames B.N., Revised methods for the mutagenicity test, Mutat. Res., 113 (1983) 173-215.

[16] Uysal A., Zengin G., Durak Y. and Aktumsek A., Screening for antioxidant and antimutagenic properties of extracts from Centaurea pterocaula as well as their enzyme inhibitory potentials, Marmara Pharm. J., 20-3 (2016) 232-242.

[17] Khaligh P., Salehi P., Farimani M.M., AliAsgari S., Esmaeili M.A. and Ebrahimi S.M., Bioactive compounds from Smilax excelsa L, J. Iran Chem. Soc., 13 (2016) 1055-1059.

[18] Ivanova A., Mikhova B., Kostova I. and Evstatieva L., Bioactive chemical constituents from Smilax excels, Chem. Nat. Compd., 46 (2010) 295-297.

[19] Schultes R.E., The Kingdom of Plants. In: Thomson WAR., editor. Medicines from the earth. New York: McGraw-Hill Book Co, 1978; pp 208.

[20] Feng Q.L., Wu J., Chen G.Q., Cui F., Kim T.N., and Kim J.O., A mechanistic study of the antibacterial effect of silver ions on Escherichia coli and Staphylococcus aureus, J. Biomed. Mate. Res., 52-4 (2000) 662-668.

[21] Lu C.L., Zhu W., Wang M., Xu X.J. and Lu C.J., Antioxidant and anti-inflammatory activities of phenolic-enriched extracts of Smilax glabra, J. Evid. Based Complement Altern. Med., 2014 (2014) 1-8.

[22] Shuo X., Ming-Ying S., Guang-Xue L., Feng X., Xuan W., Cheng-Chao S. and Shao-Qing C., Chemical Constituents from the Rhizomes of Smilax glabra and their antimicrobial activity, Molecules, 18 (2013) 5265-5287. 